Revista Latinoamericana de la Papa 21 (2): 25 - 38

http://www.papaslatinas.org/revista.html

ISSN: $1853-4961$

\title{
Growth-associated factors and pre-basic seed production of ten native potato varieties using aeroponic conditions in Kishuara - Peru
}

\section{S. Medina-Quispe ${ }^{1}$, S. Quispe-Chipana ${ }^{1}$, L.M. García-Rosero ${ }^{2 / *}$, J.E Veneros- Guevara $^{3}$, C.A. Chuquillanqui-Sotomayor ${ }^{3}$, C.A. Bolaños-Carriel ${ }^{4}$}

Received: 12/04/2017

Accepted: 27/11/2017

Accessible on line: December 2017

\section{Summary}

This experiment was carried out in the greenhouse of the sub-region agrarian direction at Kishuara district in the province of Andahuaylas of the Apurimac region of Peru under the aeroponic production system. Growth-associated factors and pre-basic seed production were evaluated in ten varieties of native potatoes using aeroponic conditions in Kishuara Peru. A complete randomized blocks design was used, and the experimental unit consisted of 12 plants spaced at $20 \mathrm{~cm}$ x $18 \mathrm{~cm}$. The variables under study were: height of the plant (average of 12 sampling plants), days to the tuber formation, survival rate (\%), days to senescence of the plant, diameter of the stem at senescence, days to the first harvest, yield, number of tubers per plant, and the average weight of tubers. Huayro variety reached the highest growth in plant height $(133 \mathrm{~cm})$, the highest yield $(981 \mathrm{~g} / \mathrm{plant})$, and the highest average weight of mini tubers/plant $(12.5 \mathrm{~g} / \mathrm{plant})$. The Q'ompis variety was the most precocious (39 days to tuber formation). The days to the first harvest were 96 days for the varieties: Duraznillo, Yana Suytu, Q'ompis and Camotillo, and 125 in Q'eq'orani. Huayro seems to be the best variety to be used for generation of new cultivars and exploitation as native variety for potato seed tuber under aeroponic production system. Our study open the possibility for production of best quality pre-basic seed for native potato production in Peru.

Additional Keywords: Aeroponic system, seed minitubers, pre-basic potato seed, genetic resources.

\footnotetext{
Autor para correspondencia. Correo electrónico:20140685@lamolina.edu.pe

Universidad Nacional de San Antonio Abad de Cusco Av. de la Cultura, Nro. 733, Cusco - Perú

Universidad Estatal Península de Santa Elena. Av. principal La Libertad, Santa Elena, Ecuador.

International Potato Center, (CIP), Av. La Molina 1895, Lima, Perú.

Department of Plant Pathology, University of Nebraska-Lincoln, Lincoln, Nebraska, USA.
} 


\section{Factores asociados al crecimiento y producción de semilla pre-básica en diez variedades de papa nativas bajo el sistema aeropónico en Kishuara - Perú}

\section{Resumen}

La investigación se llevó a cabo en el invernadero aeropónico de Kishuará -Perú. Se evaluó el comportamiento (crecimiento, características de desarrollo, así como rendimiento) de 10 variedades de papas nativas en la producción de semilla pre-básica bajo el sistema aeropónico. La unidad experimental estuvo conformada por 12 plantas distanciadas a 20 cm x $18 \mathrm{~cm}$. Se empleó el Diseño de Bloques Completos al Azar. Las variables en estudio fueron: altura de planta (promedio de 12 plantas), días a la tuberización, porcentaje de sobrevivencia, días a la senescencia de la planta, diámetro de tallo en la senescencia, días a la primera cosecha, rendimiento y número de tubérculos por planta y peso promedio de tubérculos. La variedad Huayro alcanzó el mayor crecimiento en altura de planta $(133 \mathrm{~cm})$, el mayor rendimiento ( $981 \mathrm{~g} /$ planta), y el mayor peso promedio de mini tubérculos / planta (12.5 g/planta). La variedad Q’ompis fue la más precoz (39 días a la tuberización). Las variedades: Duraznillo, Yana shuito, Q’ompis y Camotillo presentaron 96 días hasta la primera cosecha mientras que en la variedad Q'eq'orani la primera cosecha se realizó a los 125 días. La variedad Huayro aparece como promisoria para generar nuevos cultivares, así como para su explotación en la producción de semilla aeroponica. Nuestro estudio abre la posibilidad de producción de semilla prebásica de mejor calidad para la producción de papa nativa en Perú.

Palabras clave adicionales: Sistema aeropónico, producción de mini tubérculos, recursos genéticos.

\section{Introduction}

Potato is considered as staple food and plays a major role ensuring food security worldwide. The highlands of the Andean region of Peru, Bolivia and Ecuador are the center of origin of potato. In Peru, there are more than 3000 native varieties which are produced by approximately 600000 families in small orchards (Triveño et al. 2011). Native potatoes have been selected by their texture, flavor, shape and color for centuries. Additionally, small growers in the centers of origin play a special role in the conservation and evolution of these crops, especially to custody or guard exceptionally rich collections of native potatoes.
In the aim to conserve in-situ, fair trade of genetic resources, and benefit sharing, in 2014 the International center of Potato (CIP) presented the Huancavelica-Peru native potato varieties catalogue (Haan 2006).

Aeroponic technique allows higher seed rates and healthy, uniform and vigorous potato seed tubers. Aeroponic cultures can produce up to 10 times additional yield compared to conventional seed production systems (Otazu 2010). Aeroponic technique have attributes to make potato production more efficient (Nichols 2005). Aeroponic technique can reduce the number of steps for potato seed multiplication costs and improving plant health and quality of the first field 
production generation (Nichols 2005). Additionally, increasing fertilization precise, the method also increase productivity and reduction of contamination of the subterranean water table. (Nichols 2005).

Minitubers are pre-basic seeds used as starter material for propagation of certified clonal seed, and high quality mixed systems for seed production which are composed by formal and informal seed producers. The generation of seed with good quality is required to increase yield and reduce costs of production (Meza 2002). Little is known about multiplication factors required for adequate yield of certified potato seed from minitubers. Seed producers require additional technologies for seed production as well as probed protocols to be used by growers with technical expertise, in order to achieve high yield, and correct management of seedling fields to assure quality and size (Medina 2014).

Quality of potato seed tubers is the key to financial success in potato field crops with guaranteed yield and increased quality. The use of bad quality potato seed will generate weak seedlings, low germination, and delays in the emergence of sprouts. Uncertified potato seed is bedeviling rural economies of small potato producers in Peru.

Neither in Peru, specifically in the Apurimac region $\left(14.0505^{\circ} \mathrm{S}, 73.0877^{\circ}\right.$ $\mathrm{W})$, nor in the Andean zone there are investigations about the production of pre-basic native seed potato under aeroponic system and evaluations of native pre-basic seed potato yield.

Aeroponic systems for potato pre-basic seed production have been established following an increased demand for more efficient high quality seed production methods (Kang et al. 1996). This study aimed to evaluate multiplication factors such as growth (height of plant, diameter of stem at senescence) developmental characteristics (days to the tuber formation, percentage of survival, days to senescence of the plant, days to the first harvest) as well as yield in ten native prebasic seed varieties under the aeroponic system of production.

This study aimed to evaluate growthassociated factors (stem diameter, days to harvest, days to senescence survival rate, days to harvest,) the production (tubers per plant, weight, yield), and to determine the best variety of native potato for multiplication under aeroponic system.

\section{Materials \& Methods}

This experiment was carried out in the greenhouses of the sub-region agrarian direction at Kishuara district in the province of Andahuaylas of the Apurimac region $\left(13^{\circ} 41^{\prime} 24^{\prime \prime} \mathrm{S} ; 7^{\circ} 07^{\prime} 12^{\prime \prime} \mathrm{W}\right)$ at an altitude of 3666 meters above the sea level.

The aeroponic system consisted of wooden planks sawn into slats of 2" x 2", polystyrene planks of 2 " thick, density number 20, and 2.4 meters long, greenhouse insulation polyethylene film of $6 \mu \mathrm{m}$ thick, white poly-mulch, clear PVC-tubing of $16 \mathrm{~mm}$, and nebulizers of 30 liters per hour. The pumping system consisted in an electro-pump equipped with external gear pumps and hydraulic functions in the pneumatic body. Water was discharged and treated in an 1100 liters roto-plastic tank. The system was adapted to an electrical programmer. Management of the nutritive solution was implemented using standard conditions (Otazu and Chuqillanqui 2009). Electrical conductivity and $\mathrm{pH}$ were measured before application of the nutrient solution. 
In-vitro seedlings were acclimatized for four days under greenhouse conditions. Transplanting seedlings to the container was done after 30 days of rooting with a height of $(10-15 \mathrm{~cm})$. The hoeing was performed at 35 days after transplantation. Tutoring was performed 45 days after transplant, in which the following materials were used: wooden frames, raffia, and galvanized wire No. 16. Preventive controls were performed for Oidium (Oidium spp), late blight (Phytophthora infestans), potato's moth (Phthorimaea operculella), and Alternaria disease (Alternaria solani).Ten varieties of potato (Table 1) belonging to five different biological species were arranged in a randomized complete block design with three reps. Blocks allowed to control the variation due to natural light and controlled irrigation using a timer.

Table 1. Varieties used in the evaluation of multiplication factors for pre-basic native seed potato under aeroponic system in Apurimac region Peru.

\begin{tabular}{lll}
\hline Varieties & Species & CIP code $^{\mathbf{1}}$ \\
\hline Puka Aju Suytu & Solanum x chaucha & 703387 \\
Huayro & Solanum x chaucha & 704125 \\
Peruanita & Solanum goniocalyx & 703356 \\
Q'eq'orani & Solanum stenotonum & 703287 \\
Duraznillo & Solanum tuberosum subsp. andigena & 707135 \\
Yana Suyto & Solanum stenotonum & 703197 \\
Camotillo & Solanum goniocalyx & 707154 \\
Wenccos & Solanum stenotonum & INIA-Huancayo collection ${ }^{2}$ \\
Q'ompis & Solanum andigena & 700921 \\
Amarilla Tumbay & Solanum stenotonum & 706746
\end{tabular}

${ }^{1}$ CIP International potato center CGIAR research center

${ }^{2}$ Instituto Nacional de Innovacion Agraria-Peru (INIA)

Each experimental unit consisted of 12 plants. Sowing distance was $20 \mathrm{~cm} \mathrm{x} 18$ $\mathrm{cm}$. When plants reached physiological maturity (based on condition of vines) six plants were randomly chosen from each experimental unit for phenotyping analysis. Plant height was measured from the base of the stem to one centimeter left of the last leaf. Days to initial tuber formation, days to initial harvest (precocity) and days to senescence were counted.

Harvest was made sequentially every 15 days in 11 different sampling times. Yield per plant was evaluated at the end and as a result of the sum of each harvest made every 15 days, and the result was expressed in g/plant. The number of minitubers per plant was registered from plants taken randomly from each plot. The average weight of tubers is the result of the average yield per plant, divided by the total number of tubers per plant.

Statistical analysis was made in the INFOSTAT statistical package (INFOSTAT, Universidad de Cordoba, Argentina), and consisted in one-way ANOVA. To determine differences among treatment means the least significant difference - LSD $(\alpha=0.05)$ 
was used. Principal component analysis was used to reduce dimensionality of the dataset, and principal components were plotted as bi-plots to identify associations between variables and varieties. An analysis of correlation was conducted between all studied variables taken in pairs (Gomez and Gomez 1984).

\section{Results and discussion}

Among the five biological species $(S$. stenotonum, $S$. goniocalyx, S. tuberosum, S. andigena and S. $x$ chaucha) there were not statistical differences for days to initiation of tuber formation, days to harvest, days to senescence, as well as for productivity parameters: yield, average tuber weight, and tubers per plant (Table
2). There were significant differences among biological species for plant height (Table 2) where $S . x$ chaucha, $S$. stenotonum, and $S$. goniocalyx were tallest $(113 \mathrm{~cm}, 102$ and 101 respectively), and $S$. tuberosum subsp. andigena and $S$. andigena were statistically the smallest $(94 \mathrm{~cm}$, and 81 $\mathrm{cm}$, respectively) (LSD $\alpha=0.05$ ). The two varieties ( $S$. tuberosum subsp. andigena variety Duraznillo and $S$. andigena variety Q'ompis) are tetraploid cultivated potatoes usually separated as two species; however the genetic differences between $S$. tuberosum subsp. andigena and $S$. andigena are not clear (Raker and Spooner 2002)

Table 2. Analysis of variance and $F$ values for growth, behavior and yield in ten pre-basic native potato cultivars under aeroponic production system.

\begin{tabular}{|c|c|c|c|c|c|c|c|c|c|c|c|c|c|c|c|c|c|c|c|}
\hline \multirow[t]{2}{*}{$\begin{array}{l}\text { Source of } \\
\text { variation }\end{array}$} & \multirow[t]{2}{*}{ d.f. ${ }^{a}$} & \multicolumn{2}{|c|}{$\begin{array}{l}\text { Plant }^{\mathrm{b}} \\
\text { height }\end{array}$} & \multicolumn{2}{|c|}{$\begin{array}{l}\text { Days to } \\
\text { Tuber } \\
\text { initiaiton }\end{array}$} & \multicolumn{2}{|c|}{$\begin{array}{l}\text { Average } \\
\text { survival } \\
\text { rate }(\%)\end{array}$} & \multicolumn{2}{|c|}{$\begin{array}{c}\text { Days to } \\
\text { senescence }\end{array}$} & \multicolumn{2}{|c|}{$\begin{array}{l}\text { Stem } \\
\text { diameter } \\
(\mathrm{mm})\end{array}$} & \multicolumn{2}{|c|}{$\begin{array}{l}\text { Days to } \\
\text { harvest }\end{array}$} & \multicolumn{2}{|c|}{$\begin{array}{l}\text { Yield } \\
\text { (g/plant) }\end{array}$} & \multicolumn{2}{|c|}{$\begin{array}{l}\text { Tuber } \\
\text { Weight } \\
\text { (grams) }\end{array}$} & \multicolumn{2}{|c|}{$\begin{array}{l}\text { Tuber } \\
\text { number }\end{array}$} \\
\hline & & $\mathbf{M S}^{\mathrm{c}}$ & $F$ & MS & $F$ & MS & $F$ & MS & $F$ & MS & $F$ & $\overline{M S}$ & $F$ & $\overline{M S}$ & $F$ & $M S$ & $F$ & $\overline{M S}$ & $F$ \\
\hline Varieties & 9 & 642 & $14.8^{*}$ & 745 & $59.9^{*}$ & 16 & 0.5 & 2.7 & $11.8^{*}$ & 302 & $5.4^{*}$ & 351 & $4.4^{*}$ & 142 & $24.1 *$ & 3 & $6.2 *$ & 1212 & $20.4^{*}$ \\
\hline Rep & 2 & 6 & 0.1 & 0.4 & 0.03 & 238 & $6.8^{*}$ & 0.4 & 1.7 & 5 & 0.1 & 56 & 0.7 & 19 & 3.2 & 0.7 & 1.5 & 39 & 0.7 \\
\hline Error & 18 & 43 & & 12 & & 35 & & 0.2 & & 56 & & 80 & & 6 & & 0.5 & & 59 & \\
\hline Total & 29 & & & & & & & & & & & & & & & & & & \\
\hline CV (\%) & & 6.52 & & 6.52 & & 6.38 & & 3.06 & & 7.76 & & 8.41 & & 13.06 & & 7.73 & & 12.91 & \\
\hline
\end{tabular}

${ }^{\mathrm{a}}$ Degrees of freedom, ${ }^{\mathrm{b}}$ Mean square, ${ }^{*}$ Significance at $(\mathrm{P}<0.05)$

Although the analysis by biological species allows the differentiation of two marked groups

of native potatoes (smallest and largest) and to identify consistent patterns of behavior among varieties belonging to the same biological species, much of the differences by varieties where masked due to the average of same biological species.

A second analysis was conducted to investigate phenotypic differences among varieties. A significant effect was detected for the ten varieties in almost all of the variables evaluated in this study, except for survival rate (Table 2).

In general, the varieties used in this study were treated equally with optimal growth conditions under aeroponic conditions. Therefore, our results suggest that the highly significant differences among phenotypic traits are due to the genotypic potential of each variety. Similar results 
were reported by Bag et al. (2015) evaluating the yield of three potato varieties in the north eastern Himalayan region of India. They demonstrated, under aeroponic system of cultivation, where there is no shortage of nutrients, and practically no other limiting factors, the genetic potential of the variety regulates its growth and mini-tuber production potential.
The analysis of variance for plant height showed significant differences among varieties. Huayro reached the highest plant height with an average of $133 \mathrm{~cm}$, while the lowest plant height was detected in Q'ompis with an average of 81 $\mathrm{cm}$ (Figure 1). Average plant height was $102 \mathrm{~cm}$, which is lower than the data presented by Mateus et al. (2013) and Garcia (2013).
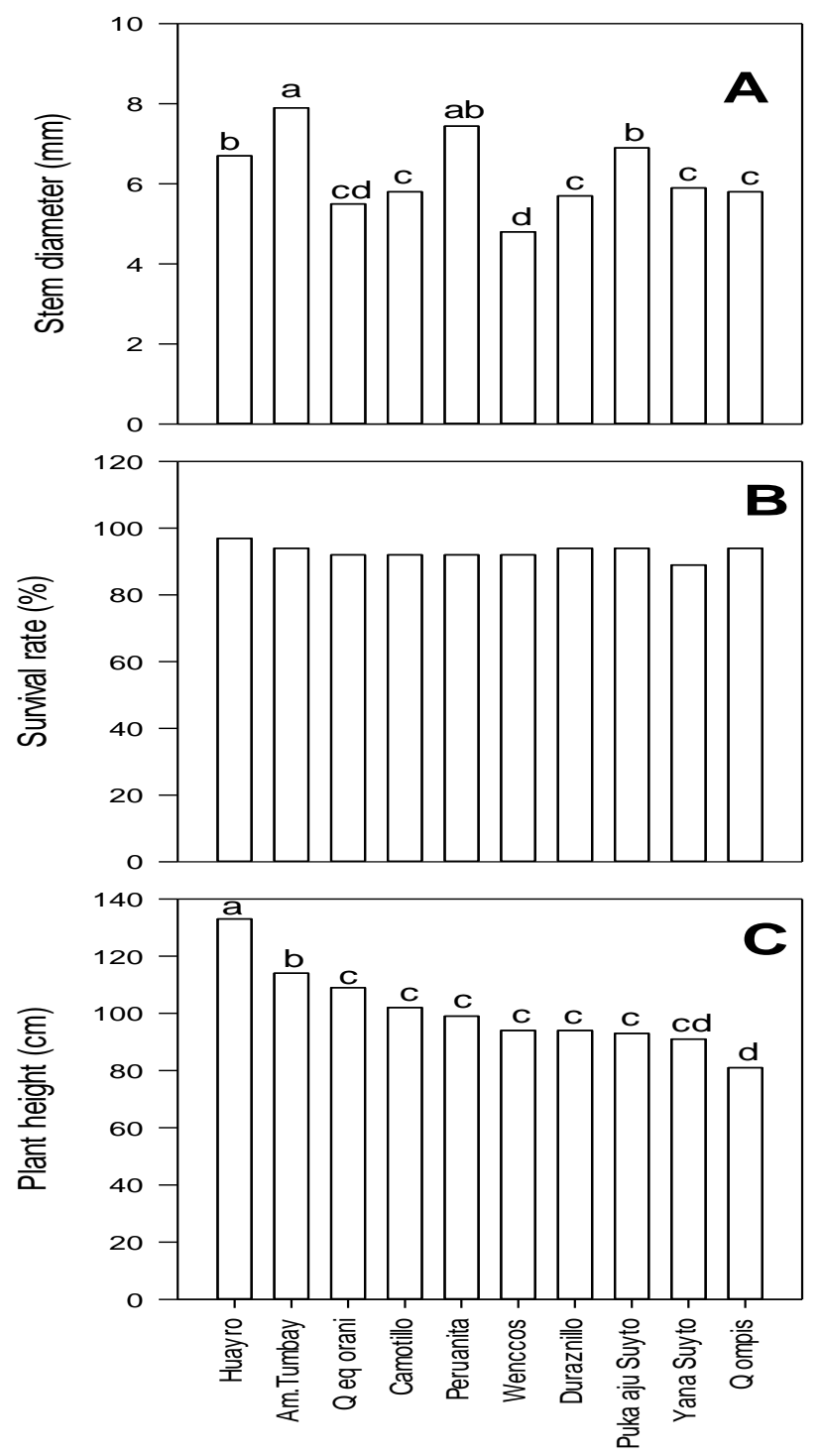

Figure 1. Means for stem diameter at senescence, survival rate and plant height in ten varieties of native potato planted under aeroponic system conditions. Letters denote differences (LSD $\alpha=0.05$ ). 
Mateus et al. (2013) conducted a study to evaluate the effect of environment on growth of ten genotypes of potato under aeroponic conditions in La Molina and Huancayo - Peru. They found higher plant height in the CIP $3939977(338 \mathrm{~cm})$ in $\mathrm{La}$ Molina than CIP $700233(16 \mathrm{~cm})$ in Huancayo. Additionally, our results were lower than Garcia (2013) who obtained an average plant height of $124 \mathrm{~cm}$ in the variety Chumarina under aeroponic conditions in La Molina- Peru.

Survival rate was not statistical different among varieties $(\mathrm{P}=0.9658)$. Stem diameter showed statistical differences among varieties (Table 2). The smallest stem diameter was showed in Wenccos variety with an average of $4.79 \mathrm{~mm}$, while the variety Amarilla Tumbay presented the largest average diameter of the stem with $7.91 \mathrm{~mm}$ (Figure 1). The overall mean of the experiment for stem diameter at senescence was $6.25 \mathrm{~mm}$.

The first variety to initiate tuber formation was Q'ompis with 39 days after transplanting (Figure 2). While the Q'eq'orani variety was the latest to initiate tuber formation with 90 days. Overall average of the experiment was 54 days to tuber formation. In other studies, Mateus et al. (2013), reported the beginning of tuber formation at 47 days (CIP 397077) and Saquinga (2012), reached the beginning of the tuber formation at 139 days in Superchola variety. Although our results are in similar range of those obtained by these authors, these differences are possibly due to external factors such as climatic conditions, fogging water temperature and formulation of nutrient solutions.

Days to harvest showed few variation; however, variety Q'eq'orani was statistically the variety with the longest harvest period (Figure 2). Q'eq'orani, under the conditions of this study, showed the highest yield (Figure 3) good adaptation.

From the analysis of variance, for days to plant senescence, there were highly significant differences within varieties (Table 2). Overall the average was 244 days to plant senescence. The variety Puka Aju Suytu showed the lowest number of days to senescence (221 days); while the highest value was presented in the varieties: Huayro, Peruanita, Q'eq'orani, Duraznillo, Camotillo, Wenccos, and Amarilla Tumbay with 250 days to senescence, respectively (Figure $2)$. These data are similar to the results obtained by Mateus et al. (2013) who reported 230 days to senescence for native potato varieties under aeroponic system. 

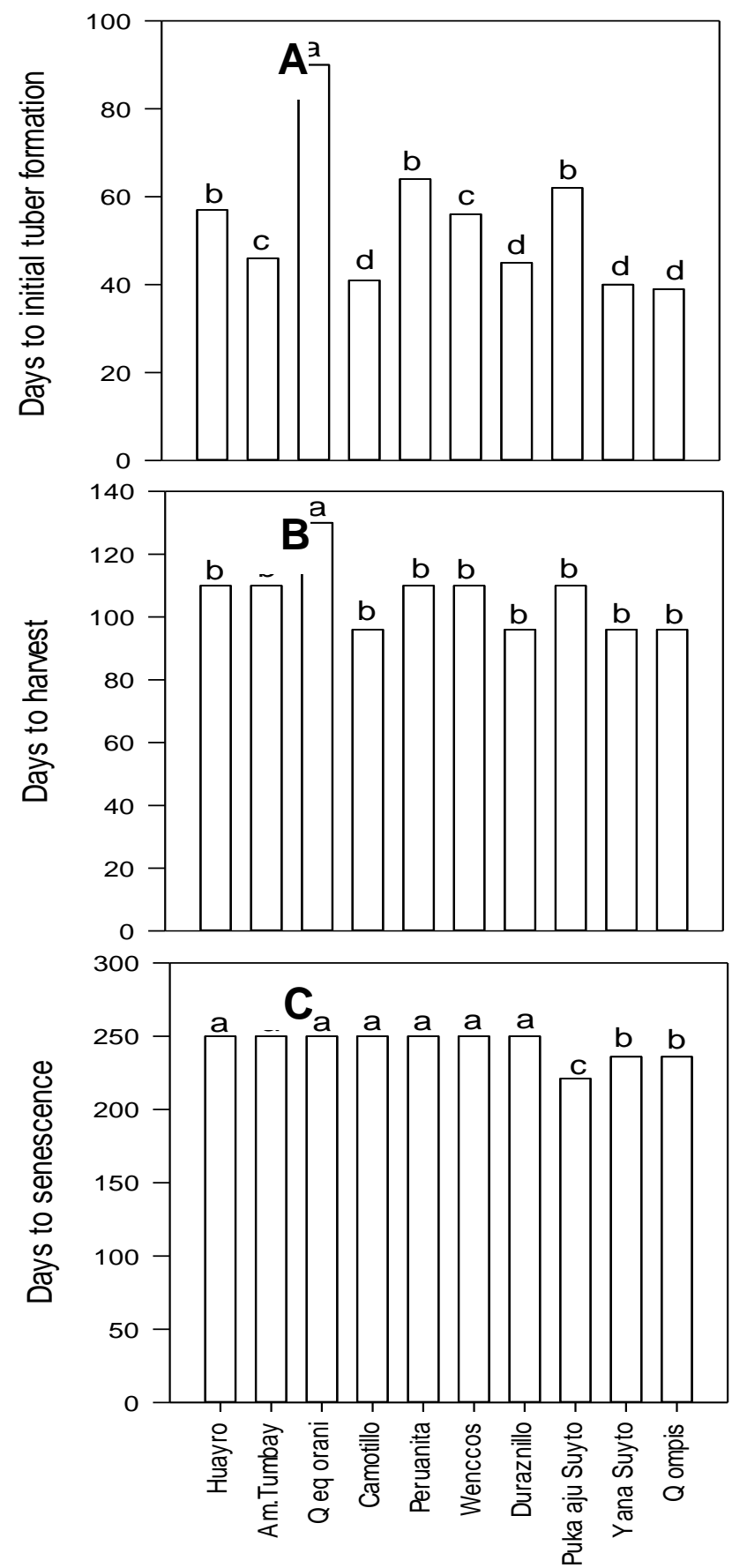

Figure 2. Means for days to initial tuber formation, days to harvest and days to senescence in ten varieties of native potato planted under aeroponic system conditions. Letters denote differences (LSD $\alpha=0.05$ ). 
Tubers per plant showed high variability of response (Figure 3). Q'eq'orani showed the highest number of tubers per plant with 102 tubers/plant. The lowest number of tubers per plant was observed in Yana Suytu with 18 tubers/plant. For potato gourmet, Nichols (2005) showed similar number of tubers per plant than this study with 37 mini-tubers/plant in the production of potato seed under aeroponic system. Overall, the number of tubers per plant was 51 tubers/plant (1226 tubers $/ \mathrm{m}^{2}$ ), higher than the result obtained by Garcia (2013) which reported 13.28 tubers/plant (332 tubers $/ \mathrm{m}^{2}$ ) in Serranita variety under aeroponic conditions. Although the average of tuber weight was similar among varieties, a significant difference was detected between Huayro (12.5 g/tuber) and the rest of varieties (Figure 3).
Yield of ten native potato varieties is summarized in Figure 3. The highest yield was detected in the variety Huayro (981 g/plant) followed by Q'eq'orani (923 g/plant). The lowest yield was detected in the variety Yana Suytu (299 g/plant), followed by Camotillo (376 $\mathrm{g} /$ plant). Overall, the yield from this study was in an average of $588 \mathrm{~g} / \mathrm{plant}$, which is higher than the result obtained by Mateus et al. (2013) with $444 \mathrm{~g} / \mathrm{plant}$ (CIP 397036). Our values were higher than the reported by Cayambe (2010) which observed an average of $428 \mathrm{~g} /$ plant registered in the variety Superchola. Our results showed higher yield values than Relloso et al. (2000) who detected an average yield of $101 \mathrm{~g} /$ plant of pre-basic commercial seed potato production under aeroponic conditions. 

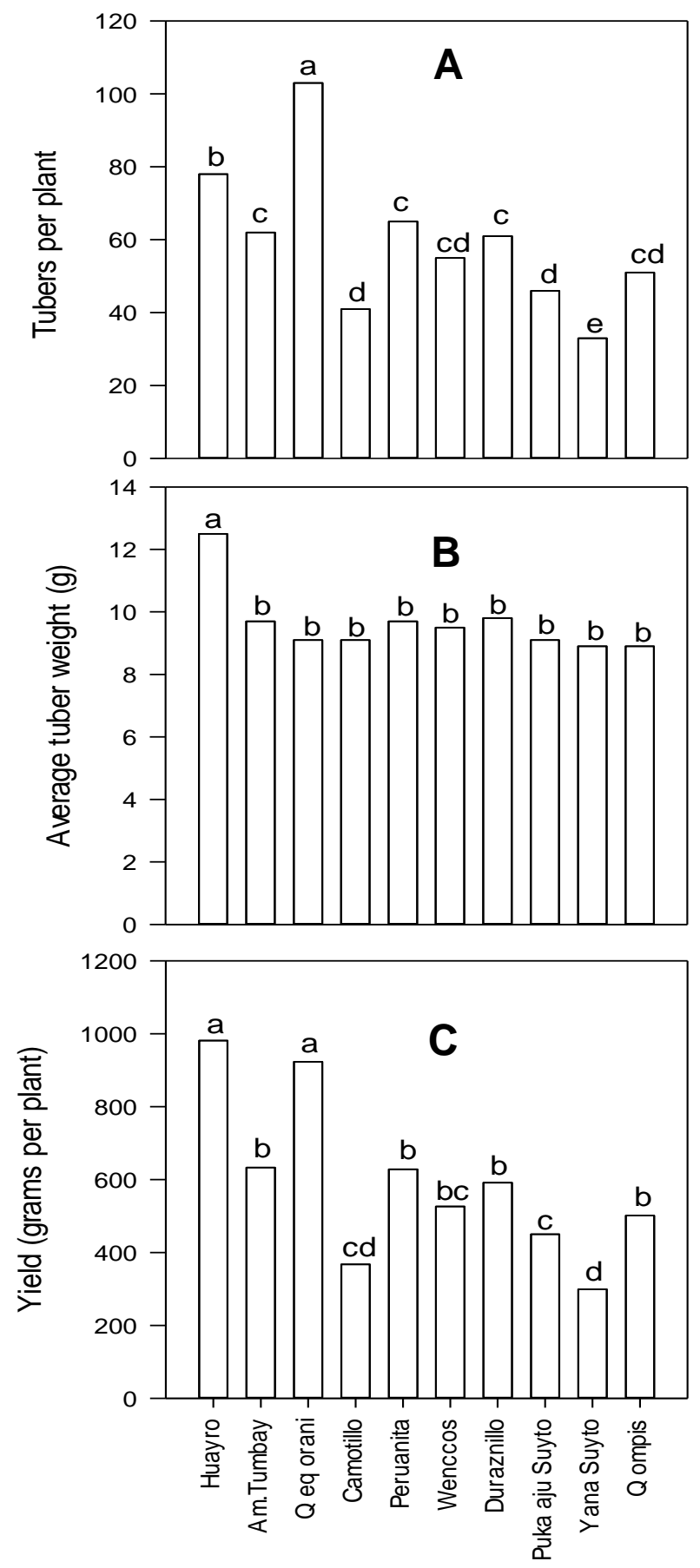

Figure 3. Means for tubers per plant, average tuber weight and yield in ten varieties of native potato planted under aeroponic system conditions. Letters denote differences (LSD $\alpha$ $=0.05)$. 
A moderately high correlation coefficient was found for the relationships between yield and tubers per plant, yield and tuber weight, yield and days to harvest, yield and height, and yield with survival rate (Table 3).

Table 3. Pearson's correlation coefficients and probabilities between variables in the evaluation of multiplication factors (growth, developmental characteristics, and yield) in ten native pre-basic seed varieties under the aeroponic system of production.

\begin{tabular}{|c|c|c|c|c|c|c|c|c|c|c|}
\hline & & $\begin{array}{l}\text { Tubers } \\
\text { per plant }\end{array}$ & Weight & Yield & $\begin{array}{l}\text { Stem } \\
\text { diameter }\end{array}$ & $\begin{array}{l}\text { Days to } \\
\text { harvest }\end{array}$ & $\begin{array}{ll}\text { Days to } \\
\text { senescence }\end{array}$ & $\begin{array}{l}\text { Survival } \\
\text { rate }\end{array}$ & $\begin{array}{l}\text { Days to } \\
\text { tuber }\end{array}$ & Height \\
\hline $\begin{array}{l}\text { Tubers } \\
\text { plant }\end{array}$ & per & 1.0 & $0.27 *$ & $<0.01$ & 0.94 & $<0.01$ & 0.15 & 0.31 & 0.01 & 0.08 \\
\hline Weight & & 0.4 & 1.0 & 0.03 & 0.45 & 0.69 & 0.29 & 0.02 & 0.83 & $<0.01$ \\
\hline Yield & & 0.9 & 0.7 & 1.0 & 0.68 & 0.02 & 0.17 & 0.07 & 0.04 & 0.01 \\
\hline $\begin{array}{l}\text { Stem } \\
\text { diameter }\end{array}$ & & 0.1 & 0.3 & 0.1 & 1.0 & 0.77 & 0.80 & 0.35 & 0.96 & 0.27 \\
\hline $\begin{array}{l}\text { Days } \\
\text { harvest }\end{array}$ & to & 0.8 & 0.1 & 0.7 & 0.1 & 1.0 & 0.60 & 0.77 & $<0.01$ & 0.17 \\
\hline $\begin{array}{l}\text { Days } \\
\text { senescence }\end{array}$ & to & 0.5 & 0.4 & 0.5 & -0.1 & 0.2 & 1.0 & 0.85 & 0.74 & 0.15 \\
\hline $\begin{array}{l}\text { Survival } \\
\text { rate }\end{array}$ & & 0.3 & 0.7 & 0.5 & 0.4 & 0.1 & -0.0 & 1.0 & 0.93 & 0.12 \\
\hline $\begin{array}{l}\text { Days to } \\
\text { tuber }\end{array}$ & & 0.8 & 0.1 & 0.7 & 0.0 & 0.9 & 0.1 & -0.1 & 1.0 & 0.36 \\
\hline Height & & 0.6 & 0.8 & 0.8 & 0.4 & 0.5 & 0.5 & 0.5 & 0.3 & 1.0 \\
\hline
\end{tabular}

Data were analyzed using Principal Component Analysis (PCA) and plotted as bi-plot of the PCA. The distribution of the samples was described using two dimensions that allow the explanation of $72.5 \%$ of the original variability of this study. Principal component 1 in the $\mathrm{X}$ axis accounted for $50.6 \%$ of the variability, and principal component 2 in the $\mathrm{Y}$ axis accounted for $21.9 \%$ of the variability (Figure 4). 


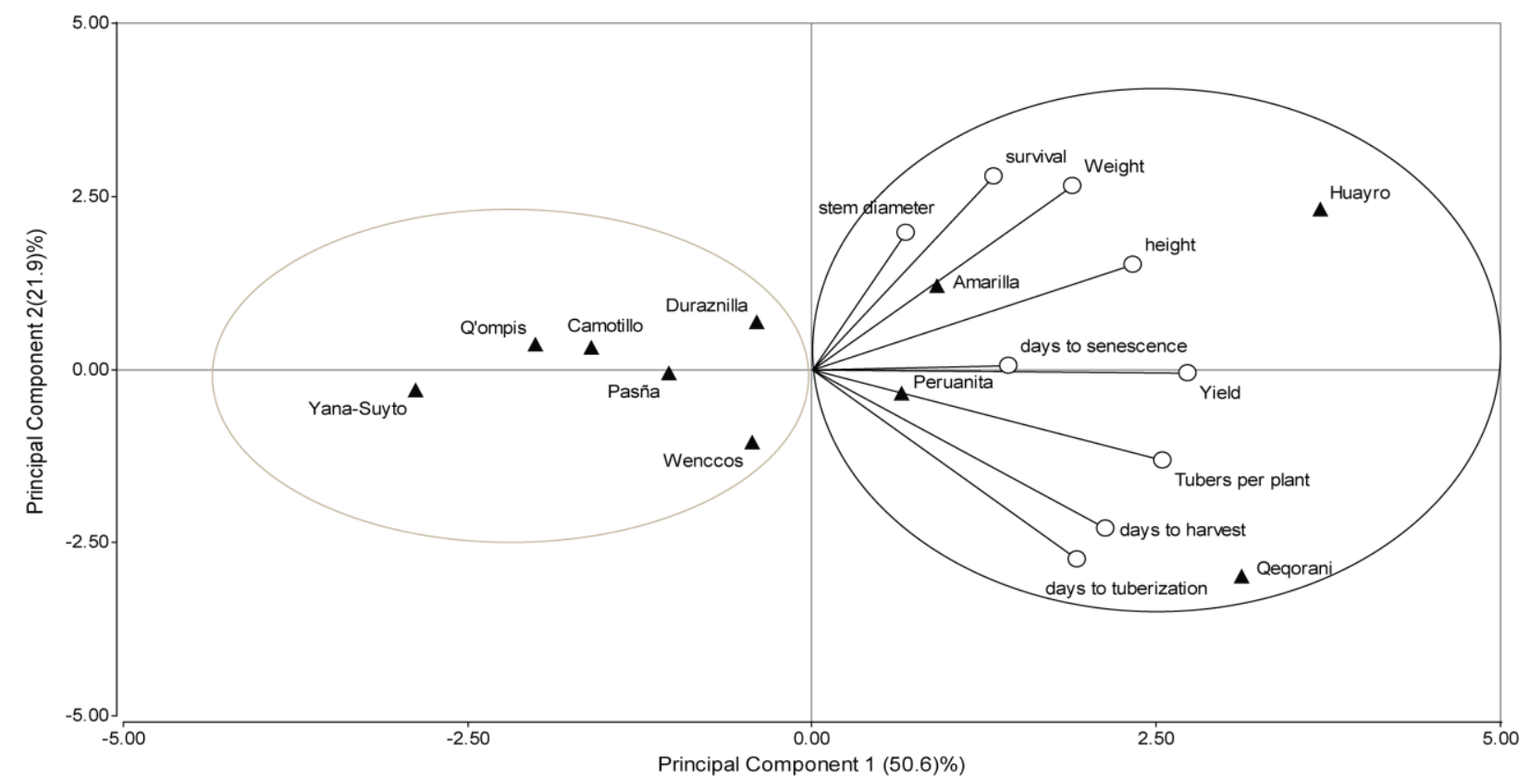

Figure 4. Bi-plot of the principal component analysis for stem diameter, survival rate, weight of tubers, height of plants, days to senescence, days to initial tuber formation, days to harvest, days to tuber formation and yield. Arrow lines are showing the correlations (+ or -) among variables.

The points near to the right handed side of the diagram correspond to the best varieties (dark-colored ellipse). Variety Huayro (the most promissory variety in this study) was clustered together with the Q'eq'orani, Amarilla Tumbay and Peruanita varieties. The rest of the varieties were clustered in the lightercolored ellipse.

In La Libertad- Peru, Huayro yield in a range $1.05-2.15 \mathrm{~kg} / \mathrm{ha}$ and 12 tubers per plant under field conditions and conventional seed production system (Pando et al. 2015). We measured yield of $0.98 \mathrm{~kg} / \mathrm{ha}$; however, our results showed substantially higher number of tubers per plant (78 tubers/plant) compared to the results presented by Pando et al. (2015).

The structure of the eigenvectors showed that tubers per plant, weight of tubers, yield, days to harvest, days to tuber formation, and height of plant had a significant weight over component 1 . Meanwhile, Days to harvest and tuber weight had significant weight over the second component.

\section{Conflict of interest}

The authors declare no conflict of interest.

\section{Acknowledgements}

We thank to the sub-region agrarian direction at Kishuara district in the province of Andahuaylas of the Apurimac region for their support and for allow us to conduct this study in their greenhouses.

\section{References}

Bag TK; Srivastava AK, Yadav SK, Gurjar MS, Diengdoh LC, Rai R, Singh S. (2015). Potato (Solanum tuberosum) aeroponics for quality seed production in 
north eastern Himalayan region of India. Indian J. Agr. Sc. 85 (10): 1360-4.

Cayambe J. M. (2010). Evaluación de soluciones nutritivas dinámicas para la producción de tubérculo - semilla categoría pre-básica en dos variedades de papa bajo el sistema aeropónico. Tesis de Ing. Agr. Quito - Ecuador, Universidad Central del Ecuador. 100 p

Factor, T.; Araújo, J.; Kawakami, F. Y Iunck, V. (2007). Produção de minitubérculos básicos de batata em três sistemas hidropônicos. Horticultura Brasileira 25: 82-87 p.

García, L. (2013). Evaluación técnica, económica y de sustentabilidad de dos métodos de producción de semilla pre básica de papa (Solanum tuberosum 1.) bajo invernadero. Tesis M.Sc. Escuela de Posgrado. Universidad Agraria la Molina. Lima. 112 p.

Gomez, A.K., and Gomez, A.A. (1984). Statistical Procedures for Agricultural Research. Second Edition. New York, NY: John Wiley \& Sons.

Haan, S. D. (2006). Catalogo de variedades de papa nativa de Huancavelica, Peru.

InfoStat versión (2011). JA Di Rienzo, F Casanoves, MG Balzarini, L Gonzalez, M Tablada. Grupo InfoStat, FCA, Universidad Nacional de Córdoba, Argentina.

Kang, J.G., Kim, Y., Om, Y.H., Kim, J.K. (1996). Growth and tuberization of potato (Solanum tuberosum L.) cultivars in aeroponic, deep flow technique and nutrient film technique culture films. J. Korean Soc. Hort. Sci. 37, 24-27.

Mateus, J.; Haan, S.; Andrade, J.; Maldonado, L.; Hareau, G.; Barker, I.; Chuquillanqui, C.; Otazú, V.; Frisancho, R.; Bastos, C.; Pereira, A.; Medeiros, C.;
Montesdeoca, F. y Benítez, J. (2013). Technical and economic analysis of aeroponics and other systems for potato mini-tuber production in Latin America. Am. J. Potato Res.: 1-12.

Medina, S. (2014). Evaluación del rendimiento de 10 variedades de papas nativas en la producción de minitubérculos bajo el sistema aeropónico. Tesis para optar el título profesional de ingeniero agropecuario. Universidad Nacional de San Antonio Abad del Cusco. 137p. Disponible en http://repositorio.unsaac.edu.pe/bitstream/ handle/UNSAAC/990/253T20140034.pdf ?sequence $=1 \&$ is Allowed $=\mathrm{y}$

Meza, A. (2002). Procedencia y tamaño de semilla, distaciamiento se siembra, fertlización orgánica y mineral en el cultivo de papa (cv. Yungay) en Sierra Central" Tesis Ing. Agr. UNALM, Lima. $65 \mathrm{pp}$.

Nichols, M. (2005). Aeroponics and potatoes. En: Acta Horticulturae 670: 201-206.

Otazú, V. (2010). Manual de producción de semilla de papa de calidad usando aeroponía. Centro Internacional de la Papa (CIP), Lima, Perú. 44 p

Otazu, V. Y Chuquillanqui, C. (2007). Producción de papa de calidad por aeroponia. En: Alternativas al uso del bromuro de metilo para la producción de semilla de papa de calidad. Centro Internacional de la Papa (CIP). Documento de Trabajo. Lima, Perú. 35 p

Pando, R; Villalobos, E; Roca, L; Cabrera, H; Pérez, J; Otiniano, R; Haan, S. (2015). Catálogo de variedades de papa nativa de Chugay, La Libertad - Perú. 204 p. ISBN 978-92-9060-467-9

Raker, Celeste M., and David M. Spooner. 2002). Chilean tetraploid cultivated potato, is distinct from the 
Andean populations. Crop Science 42 (5): 1451-1458.

Relloso, J.; Pascualena, J. Y Ritter, E. (2000). Sistema aeropónico en la producción de patata de siembra de categoría prebase. In Pascualena, J. y Ritter, E. Ed. Libro de actas del Congreso Iberoamericano de Investigación y Desarrollo en Patata. Vitoria, España. 285-297 p.

Saquinga, S. (2012). Producción de tubérculo semilla de papa (Solanum tuberosum), categoría pre-básica utilizando biol en un sistema aeropónico. Tesis Ing. Agr. Ambato, Ecuador Universidad Técnica De Ambato Facultad de Ingeniería Agronómica. 90 p.

Triveño, G., Ordinola, M., Samanamud, k., Fonseca, C., Manrique, K., Quevedo, M. (2011). Buenas Prácticas para el desarrollo de la cadena productiva de la papa: Experiencias con el proyecto INCOPA en el Perú. Centro Internacional de la Papa (CIP), Lima, Perú. 126 p. Disponible en http://cipotato.org/wpcontent/uploads/2011/07/005738-1.pdf. 